\title{
Elemental, antimicrobial and antioxidant activities of a medicinal plant Sorghum halepense
}

\author{
Abdul Yasar Khayal ${ }^{1}$, Inam Ullah ${ }^{1}$, Muhammad Nughman ${ }^{1}$, Syed Majid \\ $\mathrm{Shah}^{2}$ and Nawab Ali ${ }^{*}$ \\ 1. Department of Biotechnology and Genetic Engineering, Kohat University of Science and Technology, Kohat- \\ Pakistan \\ 2. Department of Pharmacy, Kohat University of Science and Technology, Kohat-Pakistan \\ *Corresponding author's email: nawabali_1857@yahoo.com
}

Citation

Abdul Yasar Khayal, Inam Ullah, Muhammad Nughman, Syed Majid Shah and Nawab Ali. Elemental, antimicrobial and antioxidant activities of a medicinal plant Sorghum halepense. Pure and Applied Biology. Vol. 8, Issue 1, pp795-803. http://dx.doi.org/10.19045/bspab.2019.80022

\begin{tabular}{llll}
\hline \hline Received: 13/11/2018 & Revised: 24/01/2019 & Accepted: 31/01/2019 & Online First: 12/02/2019 \\
\hline
\end{tabular}

\section{Abstract}

Sorghum halepense (L.) Pers belongs to the family Graminae or Poaceae, known as Grass family and is an important medicinal plant. It is used as fodder for animals. Present study is designated to find out medicinal properties of this plant. For this purpose the plant samples were collected and acid digested to evaluate the concentration of heavy metals such as iron $(\mathrm{Fe})$, copper $(\mathrm{Cu})$, manganese $(\mathrm{Mn})$, zinc $(\mathrm{Zn})$, lead $(\mathrm{Pb})$, cadmium $(\mathrm{Cd})$, chromium $(\mathrm{Cr})$, and nickel $(\mathrm{Ni})$ using atomic absorption spectrophotometer. Presence of heavy metals is important for medicinal plants. Then antibacterial, antifungal and antioxidant activities in Sorghum halepense was evaluated by macerating and shed drying the plant sample for fifteen days and crude extract, ethyl acetate, nhexane, chloroform and aqueous fractions were extracted. After careful analysis the concentration of heavy metals were determined as high except $\mathrm{Cd}$ and $\mathrm{Cr}$. The crude extract and other fractions of sorghum halepense showed good antibacterial activities against $P$. aeruginosa, S. epidermidis, Escherichia coli, $K$. pneumonia and B. subtillus but some of the fractions were not active against some of the bacterial strains. All the fractions showed antifungal activity against Aspergillus niger, Aspergillus fumigatus and Aspergillus flavus except ethyl acetate and aqueous fraction. The ethyl acetate, n-hexane and aqueous fractions showed excellent 2,2-diphenyl-1-picrylhydrazyl (DPPH) free radical scavenging activity but crude extract and chloroform didn't show this activity. This plant has shown various positive medicinal attributes and could be used for further bioassays and for isolation of safe herbal drugs.

Keywords: Acid digestion; Crude extract; Heavy metals; Herbal plants; Resistance; Weed

\section{Introduction}

For the treatment of various diseases medicinal plants are used globally and these plants are also important in pharmaceutical industries as raw material. These plants show medicinal properties due to the presence of bioactive compounds and there antimicrobial, analgesic, enzyme inhibition and antioxidant activities, that has various important health effects like discovery of novel drugs, diagnosis and treatment of many diseases [1, 2]. The resistance of microbial strains against 
antibiotics is a serious problem throughout the globe. Pharmaceutical industries are struggling very hard in search for new antimicrobials to overcome the challenge of resistance [3]. One possible source for the discovery of new antimicrobials to overcome this challenge of microbial resistance could be plants and hence plants are continually studied for this purpose [4]. World Health Organization has estimated that four billion people around the world uses herbal medicines for their health care [5]. This study is designed to investigate for the first time the elemental analysis, antimicrobial and antioxidant activities of sorghum halepense. Sorghum halepense as shown in figure 1, also known as Johnson grass. It belong to Gramineae family, is an herbaceous perennial plant and is a weed crop found in dry areas, ditches, cultivated fields and waste lands. Sorghum halepense has a wide range of uses such as food, beer brewing and livestock feeds and fodder. Their grain is used in biscuits, unleavened bread and tortilla for backing in confectionary industries [6].

The presence of heavy metals and other trace elements are an important criteria for a plant to be medicinal because these elements help in treatment of various diseases because of their restorative and preventive role. This plant has an amount of heavy metals and other trace elements [7]. So it is necessary to detect levels of various heavy metals and other trace elements in medicinal plants. Sorghum halepense is promoted by Wattoo $\mathrm{FH}$ et al. for treatment of various conditions as a family medicine [8]. This plant also has allelopathic potential that is well documented and this property is supposed to having antimicrobial potential dew to the presence of $\mathrm{p}$-hydroxybenzoic acid, tricin, salcolon and luteolin [9]. A researcher studied that this plant is allelopathic to many crop and weeds [10]. Antioxidants help in protecting the body during oxidative stress generating valuable health effects [11]. Plants and their metabolites are studied to obtain medication by isolation of different chemicals that has therapeutic properties for the cure of many different diseases [12]. Therefore in sorghum halepense the amount of many heavy metals, antimicrobial and antioxidant activities were analyzed to make sure whether this plant could be used as medicinal plant or not and we have obtained some positive results.

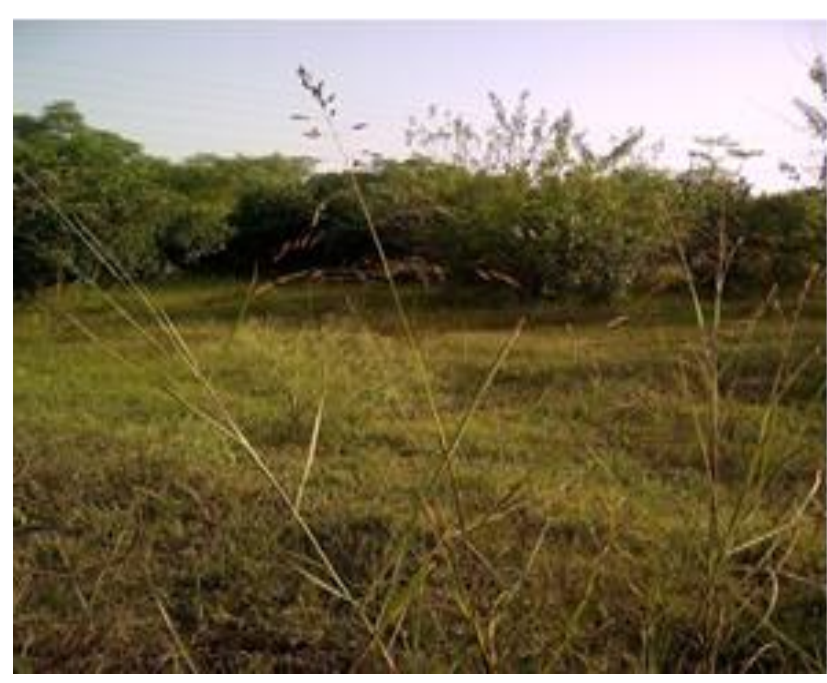

Figure 1. Sorghum halepense

Materials and methods

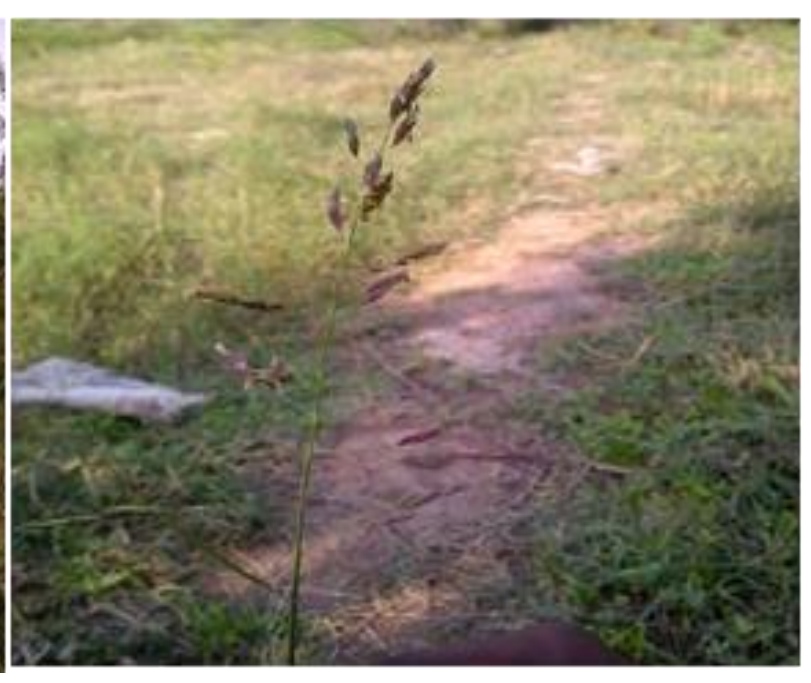

Plant collection 
Plant samples were collected from Kohat during November 2014 in order to analyze the concentration of heavy metals and to find out its antimicrobial and antioxidant activities.

\section{Acid digestion}

For heavy metals determination the plant samples were crushed lightly and sieved to pass through 2-mm mesh. In conical flask the sieved sample was treated with $65 \%$ nitric acid $\left(\mathrm{HNO}_{3}\right)$ for 24 hours at room temperature, then $5 \mathrm{ml} 70 \%$ perchloric acid $\left(\mathrm{HCLO}_{4}\right)$ was added to it and covered with watch glasses. Contents of the flask were heated on hot plate until the volume of contents in the flask reduces to $1 \mathrm{ml}$. Then the contents of the flask were cooled, diluted with distilled water and were filtered through whatman filter paper into $25 \mathrm{ml}$ volumetric flask and were diluted to the require mark.

\section{Heavy metals determination}

Heavy metals like $\mathrm{Fe}, \mathrm{Cr}, \mathrm{Mn}, \mathrm{Zn}, \mathrm{Pb}, \mathrm{Ni}$, $\mathrm{Cu}$ and $\mathrm{Cd}$ were estimated with flame atomic absorption spectrophotometer. Calibration standards $0.6,1.2,2.4$, and 4.8 were arranged from 1000ppm standard stock solution using dilution formula " $\mathrm{C}_{1} \mathrm{~V}_{1}=\mathrm{C}_{2} \mathrm{~V}_{2}$ " for each heavy metal. Before each analysis the instrument was calibrated. Table 1 shows different measurement condition for each metal under study.

Table 1. Conditions for the measuring of heavy metals

\begin{tabular}{|c|c|c|c|c|}
\hline Metals & Mode & Wavelength & Slit width & Current \\
\hline $\mathrm{Fe}$ & Absorption & $248.33 \mathrm{~nm}$ & $1.8 / 1.35 \mathrm{~nm}$ & $30 \mathrm{~mA}$ \\
\hline $\mathrm{Zn}$ & Absorption & $213.86 \mathrm{~nm}$ & $1.8 / 1.35 \mathrm{~nm}$ & $15 \mathrm{~mA}$ \\
\hline $\mathrm{Ni}$ & Absorption & $232.0 \mathrm{~nm}$ & $1.8 / 1.35 \mathrm{~nm}$ & $25 \mathrm{~mA}$ \\
\hline $\mathrm{Cu}$ & Absorption & $324.75 \mathrm{~nm}$ & $2.7 / 0.8 \mathrm{~nm}$ & $15 \mathrm{~mA}$ \\
\hline $\mathrm{Cr}$ & Absorption & $357.9 \mathrm{~nm}$ & $2.7 / 0.8 \mathrm{~nm}$ & $25 \mathrm{~mA}$ \\
\hline $\mathrm{Cd}$ & Absorption & $228.8 \mathrm{~nm}$ & $2.7 / 1.35 \mathrm{~nm}$ & $4 \mathrm{~mA}$ \\
\hline $\mathrm{Mg}$ & Absorption & $279.48 \mathrm{~nm}$ & $1.8 / 0.6 \mathrm{~nm}$ & $20 \mathrm{~mA}$ \\
\hline $\mathrm{Pb}$ & Absorption & $283.31 \mathrm{~nm}$ & $2.7 / 1.05 \mathrm{~nm}$ & $10 \mathrm{~mA}$ \\
\hline
\end{tabular}

\section{Preparation of crude extract}

The plant material was dried in shade and then crushed roughly into powder for the preparation of crude extract. And then softened in methanol with irregular shaking at room temperature for 15 days and then filtered and in rotatory evaporator the filtrate was concentrated at $40^{\circ} \mathrm{C}$. The crude extract was suspended in $500 \mathrm{ml}$ distilled water and one after the other separated with n-hexane $(3 \times 500 \mathrm{ml})$, chloroform $(3 \times 500 \mathrm{ml})$ and ethyl acetate $(3 \times 500 \mathrm{ml})$ to get $n$-hexane, chloroform and ethyl acetate fractions respectively.

\section{Antibacterial assays}

For the determination of antibacterial activity well assay was used. The bacterial strains that were used are Pseudomonas aeruginosa, Escherichia coli, Bacillus subtilis, Klebsiella pneumonia, Staphylococcus epidermidis and Staphylococcus Aureus. Under aseptic conditions the prepared Muller Hinton agar media was transferred into petri dishes and allowed to harden. The altered method of Das et al. was followed [13]. Bacterial culture equivalent to $10^{6} \mathrm{cfu}$ was inoculated on hardened media. Metallic borer was used for the formation of wells in media. $200 \mathrm{ul}$ of Dimethyl sulfoxide (DMSO) at concentration of $10 \mathrm{mg} / \mathrm{ml}$ of the stock solution of crude extract and fractions were added in the wells. The zones made by the bacterial strains after 
24 hours of incubation at $37^{\circ} \mathrm{C}$ were compared with zone made by the doxycycline that was used as standard drug.

\section{Antifungal assay}

For antifungal activity agar well dilution method was used. Three fungal strains Aspergillus niger, Aspergillus fumigatus and Aspergillus flavus were used. In DMSO four dilutions of crude extract and fractions were made i.e. $1.5 \mathrm{mg} / \mathrm{ml}, 2.5 \mathrm{mg} / \mathrm{ml}, 3.5 \mathrm{mg} / \mathrm{ml}$ and $4.5 \mathrm{mg} / \mathrm{ml}$. In sterile test tubes these fractions were poured that was combined in sea bourad dextrose agar media at $45^{\circ} \mathrm{C}$. In each tube a small piece of already grown fungus was placed and incubated for 5 days at $25^{\circ} \mathrm{C}$. Results were observed and recorded for each tube. Positive and negative control were included with only fungus and without any fungus respectively.

\section{Antioxidant activity}

For determination of antioxidant activity Blois (1958) method with slight modifications was followed [14]. Concisely, the DPPH radical solution of $1 \mathrm{mM}$ in methanol was formulated and from this solution $1 \mathrm{ml}$ was added to $3 \mathrm{ml}$ of sample solutions in ethanol and to control having no sample. After $30 \mathrm{~min}$ at $517 \mathrm{~nm}$ the absorbance was measured. In results DPPH absorbance will be inversely proportional to DPPH radical-scavenging activity. Free radicals scavenging was calculated by the following formula;
$\%$ RSA $=$ Absorbance of control Absorbance of test / Absorbance of control $x$ 100

The concentration of extract showing 50\% inhibition $\left(\mathrm{EC}_{50}\right)$ was calculated from the graph of \% RSA against the concentration of extract with ascorbic acid, quercetin, $\alpha$ tocopherol and gallic acid that were used as standards.

\section{Results and discussion}

\section{Elemental analysis}

The results shows that the concentration of some heavy metals were high like that of $\mathrm{Mn}$ from $306 \pm 11 \mu \mathrm{g} \mathrm{Kg}^{-1}$, Ni from $81 \pm 6 \mu \mathrm{g} \mathrm{Kg}^{-1}$, $\mathrm{Cr}$ was $120 \pm 8 \mu \mathrm{g} \mathrm{Kg}^{-1}$, Fe was $18 \pm 1.8 \mu \mathrm{g} \mathrm{Kg}^{-}$ ${ }^{1}$, and $\mathrm{Zn}$ range was $191 \pm 6 \mu \mathrm{g} \mathrm{Kg}^{-1}$ while others are present in relatively low amount like $\mathrm{Pb}$ from $11 \pm 2 \mu \mathrm{g} \mathrm{Kg-}{ }^{1}, \mathrm{Cu}$ from $2.24 \pm 0.6 \mu \mathrm{g} \mathrm{Kg}^{-1}$ and $\mathrm{Cd}$ from $1.1 \pm 0.1 \mu \mathrm{g}$ $\mathrm{Kg}^{-1}$ as shown in figure 2. The high concentration of some heavy metals depends on the physiographical conditions and waste generated from the area [15]. A researcher reported the concentration of some of the heavy metals in Chinese herbal plants and has found the concentration of, as we have observed of some elements as high while others in low amount [16]. Findings of our work is also in line with the work of a reporter who determined micro and heavy metals accumulation in aloe vera plant [17].

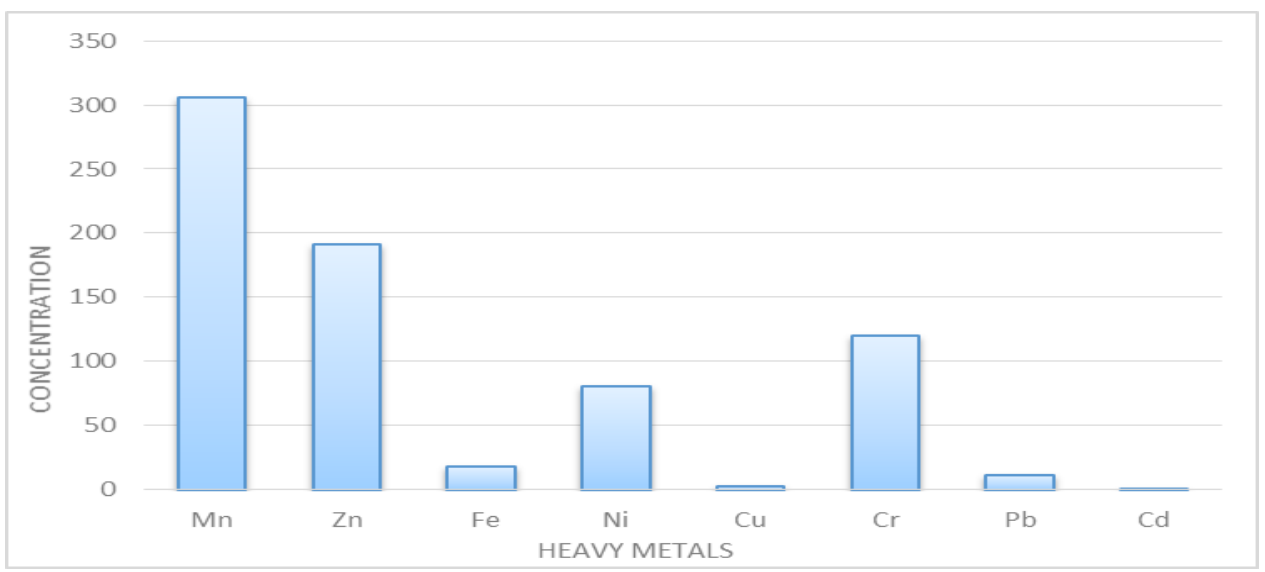

Figure 2. Concentration of heavy metals in Sorghum halepense 


\section{Antibacterial activity}

The antibacterial activity of Sorghum halepense extracts were determined by measuring zones of inhibition. The activity of crude extract, fractions and standard are shown in table 2 and figure 3 . The crude extract has shown activity against all the bacterial strains. The ethyl acetate and nhexane fractions were active against $P$. aeruginosa and $S$. epidermidis but didn't against B. subtillus, $K$. pneumoniae and $E$. coli while chloroform fraction was active against $S$. epidermidis, $P$. aeruginosa and $B$. subtillus. In this study the plant extracts were active against Bacillus subtilis and other bacterial strains. A similar antibacterial activity was also reported in Caesalpinia Bandcella in which they have tested antibacterial activity of Caesalpinia Bandcella and our results are in consistency with them [18]. The aqueous fraction of Sorghum halepense was active against all the strains except $B$. subtillus. Doxycycline that was used as standard give positive results against all five bacterial strains. Our results are similar to the results obtained by a reporter from South Korea who has reported antibacterial activity of Sorghum. They isolated different chemicals and screened them for antimicrobial activity and obtained positive results [19].

Table 2. Antibacterial activity Sorghum halepense crude extract and fractions

\begin{tabular}{|c|c|c|c|c|c|c|}
\hline & \multicolumn{7}{|c|}{ Zone of Inhibition (mm) } \\
\hline Micro-org & Ethyl act & Chloroform & Aqueous & Crude & N-hexane & Doxycycline \\
\hline E. coli & 0 & 0 & 12 & 10 & 0 & 16 \\
\hline P. aeroginosa & 9 & 12 & 9 & 15 & 10 & 19 \\
\hline K. pnemonia & 0 & 0 & 12 & 10 & 0 & 24 \\
\hline S. epidermidis & 20 & 14 & 14 & 15 & 19 & 20 \\
\hline B. subtillus & 0 & 10 & 0 & 13 & 0 & 17 \\
\hline
\end{tabular}

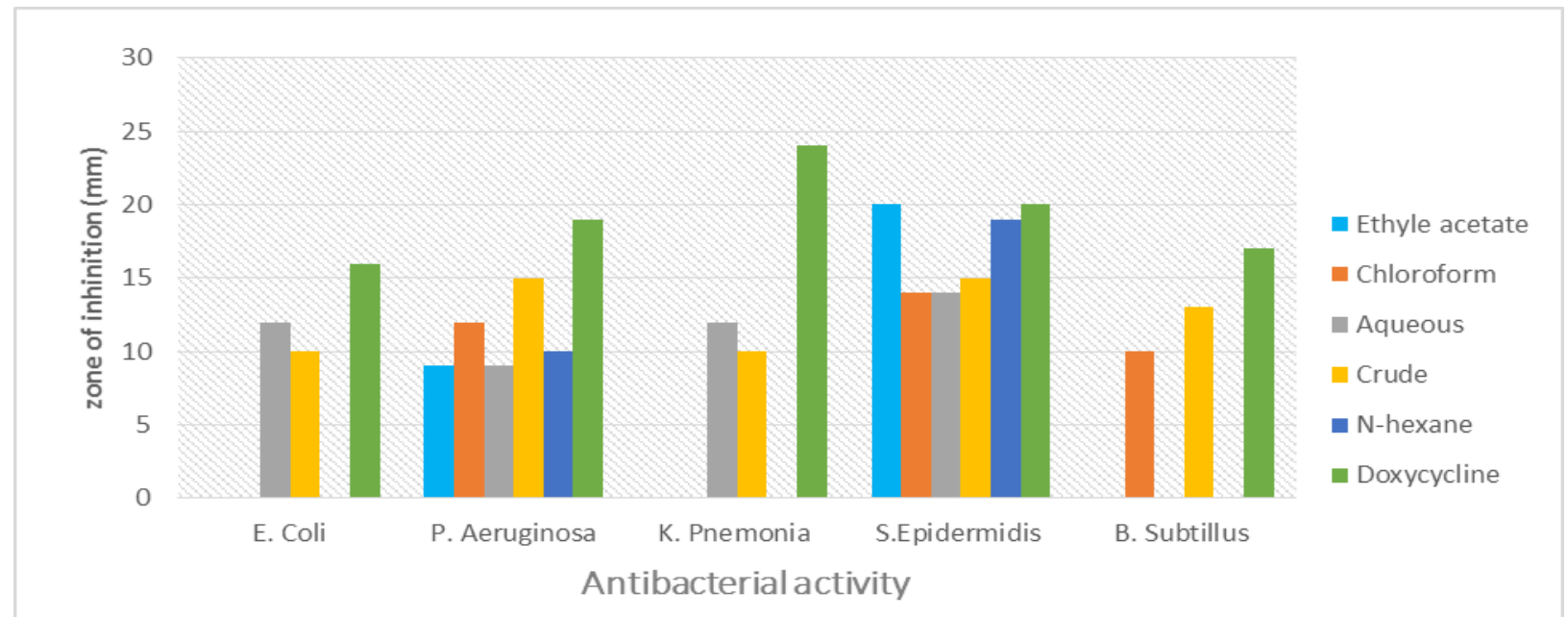

Figure 3. Antibacterial activity of sorghum halepense extracts against different bacterial strains

\section{Antifungal activity}

The crude extract and fractions of the plant have shown positive antifungal activity. The Crude extract, n-hexane fraction and chloroform fraction have shown activity against the three fungal strains used i.e. $A$. niger, A. fumigatus and A. flavus while ethyl acetate and Aqueous were inactive as shown 
in the table 3 and figure 4. For All the three fungal strains, minimum inhibitory concentration (MIC) were $2.5 \mathrm{mg} / \mathrm{ml}$ for chloroform and n-Hexane fractions while MIC for crude extract for A. niger was 2.5 $\mathrm{mg} / \mathrm{ml}$ and against $A$. fumigatus and $A$. flavus were $3.5 \mathrm{mg} / \mathrm{ml}$. Several plants have been tested that show antifungal activities [20]. As results obtained by a reporter for some medicinal plants that has shown strong activity against Aspergillus niger from Mexico [21]. Tannic acid plays an important role in antimicrobial activity of medicinal plants and in sorghum it may be due to the presence of this compound. Some phenolics are also thought to contribute in antimicrobial activity. Sorghum is reported to having these compounds [22]. Our results are consistent with the antimicrobial activities revealed by other species of the genus Sorghum but not of the sorghum halepense as we didn't find any literature on the antibacterial or antifungal activities of sorghum halepense.

Table 3. MIC of crude extract and fractions of Sorghum halepense against fungal strains

\begin{tabular}{|c|c|c|c|c|c|}
\hline Fungal strains & Ethyle act & Chloroform & Aqueous & N-hexane & Crude Extract \\
\hline A. Niger & NA & 2.5 & 0 & 2.5 & 2.5 \\
\hline A. Fumigates & NA & 2.5 & 0 & 2.5 & 3.5 \\
\hline A. Flavus & NA & 2.5 & 0 & 2.5 & 3.5 \\
\hline
\end{tabular}

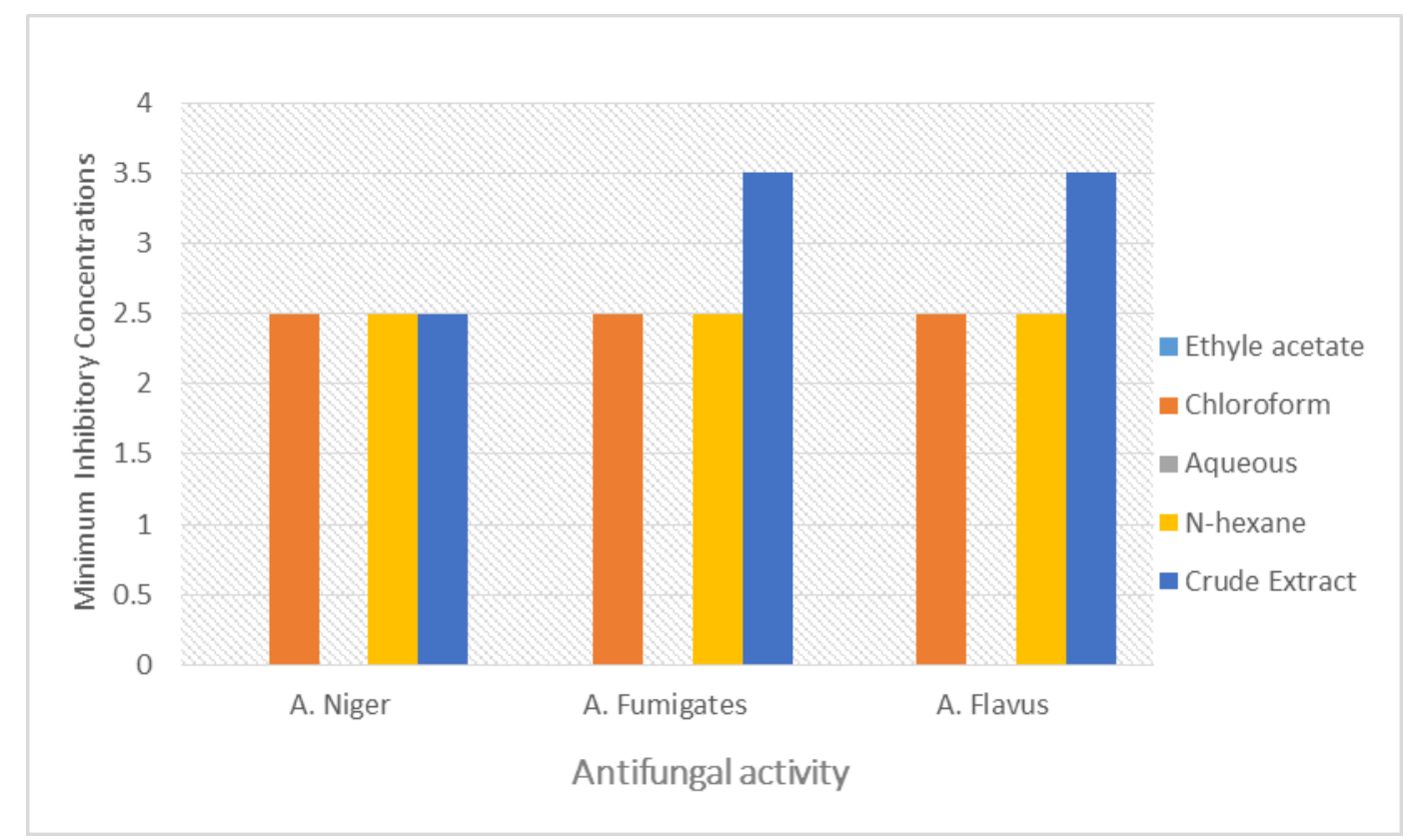

Figure 4. Antifungal activities of different extracts of sorghum halepense

\section{Antioxidant activity}

DPPH is a compound with free radical that has been commonly used for the determination of free radical scavenging or antioxidant activity [23]. For this activity plant crude extract and fractions were tested and obtained positive antioxidant results as shown in table 4 and figure 5. An excellent antioxidant activity were shown by n-hexane, ethyle acetate and aqueous fractions and had an $\mathrm{EC}_{50}$ value of $35.53 \mathrm{ug} / \mathrm{ml}, 30.34 \mathrm{ug} / \mathrm{ml}$ and $20.51 \mathrm{ug} / \mathrm{ml}$ respectively while chloroform fraction and crude extract were not active for this activity. The antioxidant 
activity of a medicinal plant was reported by a researcher who has extracted the aromatic geranyl derivative of the resinous exudates of $H$. strigosum and suggested that this plant has strong antioxidant activity [24]. A reporter has also reported antioxidant and antimicrobial activities of some sorghum cereal plants whose results are in consistency with our results for antioxidant and antimicrobial activities [19].

Table 4. Antioxidant activity and $\mathrm{EC}_{10}$ activity of Sorghum halepense.

\begin{tabular}{|c|c|c|}
\hline Test Fractions & \%Interaction DPPH 30min & $\mathbf{E C}_{\mathbf{1 0}}(\mathbf{u g} / \mathbf{m l})$ \\
\hline n-hexane fraction & 90.70 & 35.53 \\
\hline Chloroform fraction & 37.09 & - \\
\hline Ethyl acetate fraction & 94.5 & 30.34 \\
\hline Aqueous fraction & 30.34 & 20.51 \\
\hline Crude extract & 21.34 & - \\
\hline
\end{tabular}

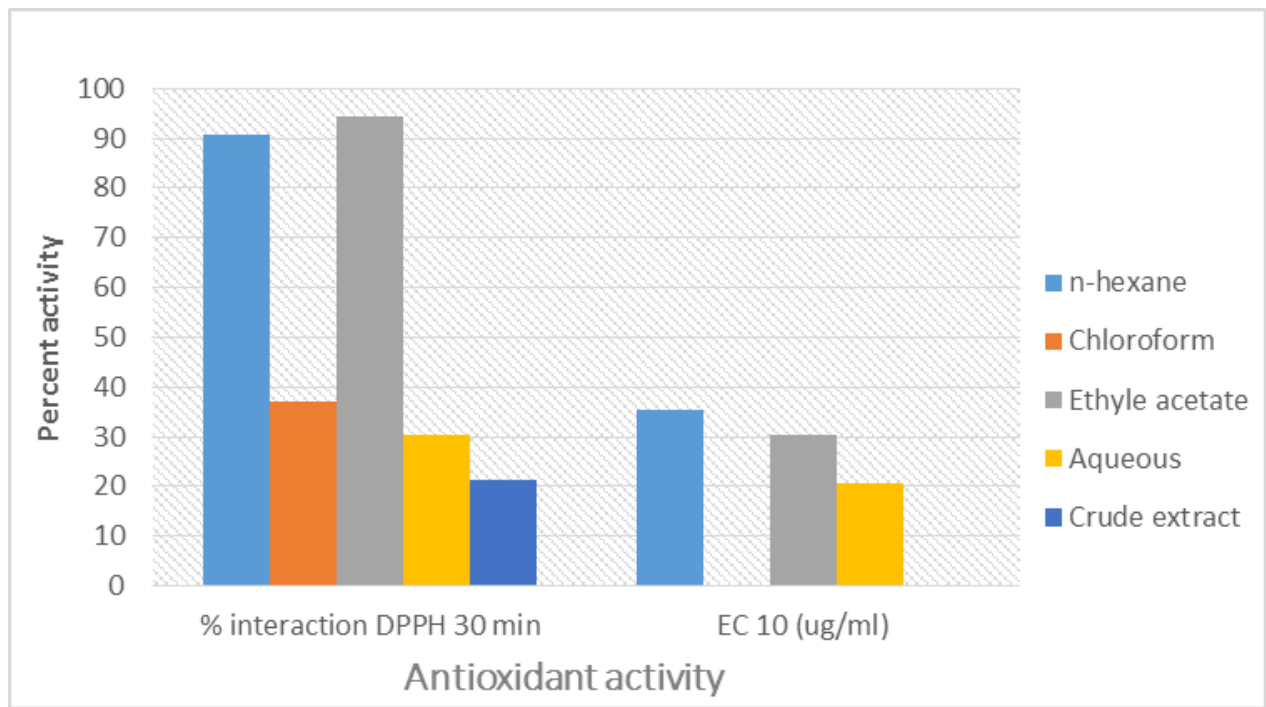

Figure 5. Antioxidant and EC50 of crude extract and fractions of Sorghum halepense

\section{Conclusion}

From this study it can be concluded that Sorghum halepense is a good absorber of metals as it has high concentrations of heavy metals and also this plant has shown good antimicrobial and antioxidant activities, so could be used as a medicinal plant.

\section{Authors' contributions}

Designed and performed the experiments: AY Khayal, I Ullah \& N Ali, Analyzed the data and contributed the reagents: N Ali, I Ullah, SM Shah \& M Nughman, Equally contributed as first author: AY Khayal \& I Ullah, Wrote the manuscript: AY Khayal, I Ullah \& N Ali.

\section{References}

1. Modak M, Dixit P, Londhe J, Ghaskadbi S \& Devasagayam TPA (2007). Indian Herbs and Herbal Drugs Used for the Treatment of Diabetes. J Clin Biochem Nutr 40(3): 163-173.

2. Trivedi PC (2004). Herbal Drugs and Biotechnology. In: Trivedi P C Ed. Pointer publications. pp 262-265.

3. Duke SO, Dayan FE, Romagni JG \& Rimando AM (2000). Natural products as sources of herbicides: current status and future trends. Weed Res (Oxford) 40(1): 99-111. 
4. Angeh JE, Huang X, Sattler I, Swan GE, Dahse H, Hartl A \& Eloff JN (2007). Antimicrobial and anti-inflammatory activity of four known and one new triterpenoid from Combretum imberbe (Combretaceae). J Ethnopharmacol 110: 56-60.

5. Farnsworth NR, Akerele O, Bingel AS, Soejarto DD \& Guo Z (1985). Medicinal plants in therapy. $B$ World Health Organ. 63: 965-981.

6. McWhorter CG (1971). Introduction and spread Johnson grass in the United stated. Weed Sci 05: 496-500.

7. Kaneez FA, Qadiruddin M, Kalhoro MA, Khaula S \& Badar Y (2001). Determination of major and trace elements in Artemisia elegantissima and Rhazya stricta and their relative medicinal uses. Pakistan $J$ Sci Ind $R$ 44(5): 291-293.

8. Wattoo FH, Tirmizi SA, Wattoo MHS, Anjum A, Iqbal J, Ghanghro AB \& Khan MY (2008). Analytical investigation of selected inorganic nutrients of desert growing Aloes. $J$ Chem Soc Pakistan 30(3): 394-399.

9. Baerson SR, Dayan FE, Rimando AM, Nanayakkara ND, Liu CJ, Schröder J, Pan Z, Kagan IA, Pratt LH \& Cordonnier-Pratt MM (2008). A functional genomics investigation of allelochemical biosynthesis in Sorghum bicolor root hairs. J Biol Chem 283(6): 3231-3247.

10. Roth CM, Shroyer JP \& Paulsen GM (2000). Allelopathy of sorghum on wheat under several tillage systems. Agron J 92(5): 855-860.

11. Jakus V (2000). The role of free radicals, oxidative stress and antioxidant systems in diabetic vascular disease. Bratisl Med J 101: 541-551.

12. Beringer $\mathrm{P} \&$ Felton 1 (2005). Pharmaceutical and medicinal agents. In: Steven. G. Alfonoso. R Ed. Remington"
The Science and Practice of Pharmacy. Lipincott william and Wilkins publ. pp 1350-1380.

13. Das MP, Dhanabalan R, Doss A \& Palaniswamy M (2009). Phytochemical screening and antibacterial activity of aqueous and methanolic leaf extracts of two medicinal plants against bovine mastitis bacterial pathogens. Ethnobotanical leaflets. 2009(1): 15 .

14. Blois MS (1958). Antioxidant Determinations by the Use of a Stable Free Radical. Nature 181: 1199-1200.

15. Rai S, Sharma DK, Arora SS, Sharma M \& Chopra AK (2011). Concentration of the heavy metals in Aloe vera $\mathrm{L}$ (Aloe barbadensis Miller) Leaves collected from different geographical locations of India. Ann Biol Res 2(6): 575-579.

16. Wong MK, Tan P \& Wee YC (1992). Heavy Metals in Some Chinese Herbal Plants. Biol Trace Elem Res 36: 135142.

17. Swapnil R, Sharma D, Arora SS \& Chopra AK (2011). Concentration of heavy metals in Aloe Vera L. (Aloe Barbadensis Miller) Leaves collected from different geographical locations of India. Ann of Biol Res 2(6): 575-579.

18. Khan HU, Ali I, Khan AU, Naz R \& Gilani AH (2011). Antibacterial, antifungal, antispasmodic and $\mathrm{Ca}++$ antagonist effects of Caesalpinia bonducella. Nat Prod Res 25(4): 444449.

19. Kil HY, Seong ES, Ghimire BK, Chung IM, Kwon SS, Goh EJ, Heo K, Kim MJ, Lim JD, Lee D \& Yu CY (2009). Antioxidant and antimicrobial activities of crude sorghum extract. Food Chem 115(4): 1234-1239.

20. Moghaddam KM, Arfan M, Rafique J, Rezaee S, Jafari Fesharaki P, Gohari AR \& Shahverdi AR (2009). The antifungal activity of Sarcococca 
saligna ethanol extract and its combination effect with fluconazole against different resistant Aspergillus species. Appl Biochem Biotech 162: 127-133.

21. Ruiz-Bustos E, Velazquez C, GaribayEscobar A, Garcia Z, Plascencia Jatomea M, Cortez-Rocha MO, Hernandez Martinez J \& Robles Zepeda RE (2009). Antibacterial and antifungal activities of some Mexican medicinal plants. J Med Food 12: 1398-402.

22. Awika JM \& Rooney LW (2004). Sorghum phytochemical and their potential impact on human health. Phytochem 65: 1199-1221.

23. Amarowicz R, Pegg RB, RahimiMoghaddam P, Barl B \& Weil JA (2004). Free radical-scavenging capacity and antioxidant activity of selected plant species from the Canadian prairies. Food Chem 84: 551562.

24. Modak B, Rojas M, Torres R, Rodilla J \& Luebert F (2007). Antioxidant activity of a new aromatic geranyl derivative of the resinous exudates from Heliotropium glutinosum. Phil Mol 12: 1057-1063. 